DOI: 10.20472/BMC.2018.007.003

\title{
SASIPA POJANAVATEE
}

Silpakorn University, Thailand

\section{THE SENSITIVITY OF THAILAND CORPORATE BOND VALUES TO INTEREST RATE CHANGES}

\begin{abstract}
:
The purpose of this study is to examine the volatility of the domestic corporate bond market value to changes in interest rates using duration and convexity techniques. The samples have been divided into two groups both of which have a coupon bond that pays interest semiannually. First, there is a seven-year corporate bond group. Second, there is a ten-year corporate bond group. The findings suggest that all seven-year bonds have the same level of price volatility when interest rates changes. The evidence also suggests that interest rate change effect ten-year corporate bond's price at the same level. This study concludes that, as a measure of a bond's interest rate risk, seven-year bonds tend to be less volatile when interest rates change in comparison with ten-year bonds. The duration is less than bond's maturity. The study finds evidence consistent with the typical results reported by previous studies. The price of corporate bonds move in the opposite direction of a change in interest rates, but the percentage change is not the same for all bonds.
\end{abstract}

\section{Keywords:}

Duration, Convexity and Thailand

JEL Classification: G17 


\section{Introduction}

Bond price is a function of the promised payments. A company and financial institution might originate a corporate bond in the primary market. This corporate bond might then be sold in the secondary money market. Corporate bonds are issued in par value, and have a standard coupon payment structure. The investor earns income through this process by receiving interest from the issuer until the bond matures. At that point, the investor can reclaim the face value of the bond. To use effective bond portfolio strategies, it is necessary to understand the price volatility of bonds resulting from changes in interest rates. The obvious way to measure a bond's price sensitivity as a percentage of its current price to changes in interest rates is to change rates by a small number of basis points and calculate how its price will change.

A fundamental principle of bond investing is that market interest rates and bond prices generally move in opposite directions (Bremmer \& Kesselring, 1992; Keen, 2010). This means that when interest rates go up, the price of fixed rate bonds fall and vice versa. The degree and direction to which bond prices are related to the interest rates are important not only for investors and fund managers with regard to their investment strategies, but also to academics and policy makers examining the implications of investing in domestic bond markets. This study provides insight into how a corporate bond will react to yield changes in the context of Thailand.

There are a number of previous studies that focused on bond price sensitivity. These include studies by Chance (1990), Longstaff and Schwartz (1995), and Acharya and Carpenter (2002). These study concludes that corporate bonds are less sensitive to interest rates than default risk free bonds. However, Jacoby (2003) and Kraft and Munk (2007) argue that the Treasury bond prices are less sensitive than corporate bond prices. In addition, Ivanovski, Stojanovski, and Ivanovska (2013) define and study Treasury bonds on the Macedonian Stock Exchange and they conclude that Treasury bonds are not sensitive to interest rate changes. Several empirical studies provide information about this sensitivity; for example Duffee (1998), Jarrow and Yildirim (2002), as well as Bakshi, Madan, and Zhang (2006). These studies suggest that the sensitivity of a corporate bond to interest rate changes can either be greater or smaller than the similar Treasury bond.

It can be seen that extensive work has been conducted on bond price sensitivity, but an extension of this work to the Thai bond market is somewhat limited. This study tests the sensitivity of corporate bonds on the Thai stock market to interest rate changes using examples of several bonds with different maturities and coupon rates. The basic approach is to estimate the likely change in interest rates for a particular level of confidence and multiply this by the interest rate sensitivity of the portfolio, which is typically the modified duration. Therefore, the findings of this study would provide fund managers of fixed income mutual funds and investors a quick and precise understanding of bond price sensitivity to interest rate changes. 
The remainder of this paper is organized as follows: Section II defines duration formally. Section III provides the formal analysis of corporate and Treasury bond duration in a general setting. Section IV presents the results of the empirical analysis. Finally, Section $\checkmark$ provides the conclusions of this study.

\section{Methodology}

There are three variables as determinants of bond price volatility, namely a bond's term to maturity, initial required market yield, and coupon rate. A bond's term to maturity is positively related to a bond's price volatility, while the initial required market yield and coupon rate are inversely related to a bond's price volatility (Hubbard, 2008; Lwabona, 2000). A better measure of bond price volatility is duration, which combines the attributes of both a bond's term to maturity and coupon rate.

Macaulay's duration and modified duration are commonly applied in the management of bond portfolios to measure the sensitivity of bond prices to changes in interest rates. The concept of duration was introduced by Macaulay (1938) and he suggested that investors can use the effective maturity (Macaulay Duration) of a bond as a measure of interest rate sensitivity. Therefore, modified duration measures how small changes in the yield to maturity affect the bond's price (Samuelson, 1945).

In order to see the difference between nominal maturity and time of effective return of initial investment in bonds, this study calculates duration of the bonds on the Thai stock market, as measured in years, using the following equation:

$$
D_{M a c}=\sum_{t=1}^{n} t \frac{\frac{C_{t}}{(1+y)^{t}}+\frac{F V_{n}}{(1+y)^{n}}}{P}
$$

It obtains a result similar as the following formula:

$$
D_{M a c}=\sum_{t=1}^{n} t \frac{\frac{F C F_{t}}{(1+y)^{t}}}{P}
$$

Assuming that a bond matures in $n$ years with a face value of $F V$ and it has an annual coupon payment equal to $C$ from the bond receivable at time $t$, the cash flows equals to the $F C F$ from the bond receivable at time $t$. The price of the bond denoted as $P$ and $y$ is the yield to maturity. The sum of these products represents the weighted average maturity of the bond, or Macaulay's duration $\left(D_{M a c}\right)$.

Then, modified duration ( $D_{\text {Mod }}$ ) will be applied to measure how small changes in the yield to maturity affect the bond's price. Modified duration refers to Macaulay's duration in equation (2) above, divided by $(1+y)$; and represented as: 


$$
D_{\text {Mod }}=\frac{D_{M a c}}{(1+y)}
$$

Modified duration is a proxy for the change in a bond's price as yield to maturity changes. Since duration and yield to maturity are inversely related, when interest rates change, the corresponding change in a bond's price can be related to a change in the yield to maturity, as follows:

$$
\frac{\Delta P}{P}=-D_{M a c}\left[\frac{\Delta(1+y)}{(1+y)}\right]
$$

After denoting the change in price as $\Delta P$ and the initial price as $P$, and then recalling equation (3) and noting that $[\Delta(1+y)]$ is equal to $\Delta y$, equation (4) can be rewritten as:

$$
\frac{\Delta P}{P}=-D_{\text {Mod }}(\Delta y)
$$

Equation (5) shows that bonds with shorter duration are less sensitive to interest rate changes compared with bonds with longer duration. Therefore, there is a negative relationship between modified duration and the approximate percentage change in a bond's price for a given change in yield to maturity (Ivanovski et al., 2013; Lwabona, 2000).

The modified duration estimation is a relatively good predictor of changes in the value of an asset for small interest rate changes but can be inaccurate for large interest rate changes. On the other hand, the convexity method is a relatively good predictor of changes in a bond price when interest rates change by more than a small amount. The degree of convexity shows how much a bond's price changes in response to a change in interest rate (Ivanovski et al., 2013; Livingston \& Zhou, 2005). The estimated bond convexity $(\mathrm{CON})$ is:

$$
\operatorname{CON}=\frac{1}{P} \sum_{t=1}^{n} \frac{t(t+1)\left[\frac{C_{t}}{(1+y)^{t}}+\frac{F V_{n}}{(1+y)^{n}}\right]}{(1+y)^{n+2}}
$$

Given this, equation (6) can be rewritten as:

$$
\operatorname{CON}=\sum_{t=1}^{n} t^{2} \frac{\left[\frac{F C F_{t}}{(1+y)^{t}}\right]}{P}
$$

The bond convexity is annualized by dividing the calculated convexity by the number of payments per year squared. The importance of using duration and convexity is that they provide insight into how a coupon bond will react to yield changes. Then, the study 
measures how a basis point change in yield affects the price of corporate bonds based upon the following equation:

$$
\frac{\Delta P}{P}=-D_{M o d}(\Delta y)+\frac{1}{2} \operatorname{CON}(\Delta y)^{2}
$$

Using duration and convexity measures together gives a better approximation of the actual price change for a large movement in the interest rate. In addition to improving this estimate, convexity can also be used to compare bonds with the same duration.

\section{The Data}

In this section, the study describes and summarizes the sample of corporate bonds. The data of long-term coupon bonds come from the Thai Bond Market Association. The study sample covers Thai corporate bonds issued in 2016 within the A-rated category and pay interest semi-annually. The sample includes a total of 32 corporate bonds, which are divided in two groups. The first group consists of corporate bonds with seven years of maturity, which includes 14 corporate bonds. The second group consists of corporate bonds with ten years of maturity, and which consists of 18 corporate bonds. The Thai Government, as issuer of the bonds has to be viewed as a default-free entity. Thus, the risk free rate should be the long term government bonds rate that will be used as a discount rate. The study uses the risk free rate of return on a Treasury bond ( $\mathrm{T}$ bond) issued on 2016 by the Thai Government. Risk free rates that will be used for estimation in this paper are $2.56 \%$ for corporate bonds with seven years of maturity and $3.5 \%$ for corporate bonds with ten years of maturity.

Table 1 and Table 2 report data for long-term corporate bonds with seven years of maturity and ten years of maturity, respectively. The observations are sorted according to the credit rating order per the TRIS Rating system.

Table 1. Seven-Year Corporate Bonds

\begin{tabular}{|c|c|c|c|c|c|}
\hline No. & $\begin{array}{c}\text { Corporate } \\
\text { Bonds }\end{array}$ & $\begin{array}{l}\text { Credit } \\
\text { Rating }\end{array}$ & Issue Date & $\begin{array}{c}\text { Maturity } \\
\text { Date }\end{array}$ & $\begin{array}{c}\text { Coupon Rate } \\
(\%)\end{array}$ \\
\hline 1 & DTN237A & $\mathrm{AA}+$ & $22 / 7 / 2016$ & 22/7/2023 & 3.01 \\
\hline 2 & CPFTH231A & $A+$ & $20 / 1 / 2016$ & 20/1/2023 & 3.47 \\
\hline 3 & CPFTH237A & $A+$ & $15 / 7 / 2016$ & $15 / 7 / 2023$ & 3.09 \\
\hline 4 & BJC239A & $A_{+}$ & 7/9/2016 & $7 / 9 / 2023$ & 3.07 \\
\hline 5 & KTC23NA & $A+$ & $30 / 11 / 2016$ & $30 / 11 / 2023$ & 3.50 \\
\hline 6 & BJC23DA & $A_{+}$ & $8 / 12 / 2016$ & $8 / 12 / 2023$ & 3.77 \\
\hline 7 & KTC23DA & $A+$ & 29/12/2016 & 29/12/2023 & 3.50 \\
\hline 8 & TICON235A & A & $18 / 5 / 2016$ & $18 / 5 / 2023$ & 3.35 \\
\hline 9 & BEM236A & A & $24 / 6 / 2016$ & $24 / 6 / 2023$ & 3.00 \\
\hline
\end{tabular}




\begin{tabular}{l|l|l|r|r|l}
\hline 10 & CENTEL239A & A & $29 / 9 / 2016$ & $29 / 9 / 2023$ & 2.97 \\
\hline 11 & BTSC23NA & A & $10 / 11 / 2016$ & $10 / 11 / 2023$ & 3.30 \\
\hline 12 & THAI23DA & $\mathrm{A}$ & $23 / 12 / 2016$ & $23 / 12 / 2023$ & 3.66 \\
\hline 13 & PL232A & $\mathrm{A}-$ & $24 / 2 / 2016$ & $24 / 2 / 2023$ & 3.05 \\
\hline 14 & CK233A & $\mathrm{A}-$ & $7 / 3 / 2016$ & $7 / 3 / 2023$ & 3.36 \\
\hline
\end{tabular}

Table 1 summarizes corporate bonds with seven years of maturity issued in 2016. The AA+-rated category represented $7.14 \%$ of total corporate bond issuance. This was followed by A+-rated (42.86\%), A-rated (14.29\%) and A rated (35.71\%).

Table 2. Ten-Year Corporate Bonds

\begin{tabular}{|c|c|c|c|c|c|}
\hline No. & $\begin{array}{l}\text { Corporate } \\
\text { Bonds }\end{array}$ & $\begin{array}{l}\text { Credit } \\
\text { Rating }\end{array}$ & Issue Date & $\begin{array}{l}\text { Maturity } \\
\text { Date }\end{array}$ & $\begin{array}{c}\text { Coupon Rate } \\
(\%)\end{array}$ \\
\hline 1 & DTN267A & $\mathrm{AA}+$ & $22 / 7 / 2016$ & $22 / 7 / 2026$ & 3.19 \\
\hline 2 & GLOW265A & AA- & $18 / 5 / 2016$ & $18 / 5 / 2026$ & 2.81 \\
\hline 3 & BDMS266A & AA- & $24 / 6 / 2016$ & $24 / 6 / 2026$ & 2.99 \\
\hline 4 & CPFTH261A & $A_{+}$ & $20 / 1 / 2016$ & $20 / 1 / 2026$ & 3.87 \\
\hline 5 & KTC262A & $A_{+}$ & $17 / 2 / 2016$ & $17 / 2 / 2026$ & 3.85 \\
\hline 6 & KTC262B & A+ & $17 / 2 / 2016$ & $17 / 2 / 2026$ & 3.85 \\
\hline 7 & CPFTH267A & A+ & $15 / 7 / 2016$ & $15 / 7 / 2026$ & 3.46 \\
\hline 8 & BJC269A & A+ & $7 / 9 / 2016$ & $7 / 9 / 2026$ & 3.80 \\
\hline 9 & KTC269A & A+ & 22/9/2016 & $22 / 9 / 2026$ & 3.50 \\
\hline 10 & IVL260A & $A_{+}$ & $20 / 10 / 2016$ & $20 / 10 / 2026$ & 3.68 \\
\hline 11 & KTC26NA & A+ & $30 / 11 / 2016$ & $27 / 11 / 2026$ & 4.00 \\
\hline 12 & BJC26DA & At & $8 / 12 / 2016$ & $8 / 12 / 2026$ & 4.27 \\
\hline 13 & MPSC26DA & At & 28/12/2016 & 28/12/2026 & 4.22 \\
\hline 14 & KTC26DA & $A_{+}$ & 29/12/2016 & 29/12/2026 & 4.00 \\
\hline 15 & BEM266A & A & $24 / 6 / 2016$ & $24 / 6 / 2026$ & 3.30 \\
\hline 16 & CENTEL269A & A & 29/9/2016 & 29/9/2026 & 3.39 \\
\hline 17 & BTSC26NA & A & $10 / 11 / 2016$ & $10 / 11 / 2026$ & 3.87 \\
\hline 18 & THAI26DA & A & $23 / 12 / 2016$ & $23 / 12 / 2026$ & 4.35 \\
\hline
\end{tabular}

As shown in Table 2, the largest portion of the ten-year corporate bond group was in the $A+$ rated category $(61.11 \%)$, followed by the $A$ rated $(22.22 \%)$, AA- rated $(11.11 \%)$, and $A A+$ rated $(5.56 \%)$.

\section{Empirical Analysis}

The study started its analysis calculation with the duration of coupon bonds using Eq. (2) and Eq. (3). The results of bond convexity were obtained by using Eq. (7). Table 3 reports the results of the corporate bond group with seven years maturity. The results 
of ten-year corporate bonds are presented in Table 4. Both tables show the results ranked in descending order.

Table 3. Estimation of seven-year corporate bonds

\begin{tabular}{l|l|c|c|c|c}
\hline No. & $\begin{array}{c}\text { Corporate } \\
\text { Bonds }\end{array}$ & $\begin{array}{c}\text { Credit } \\
\text { Rating }\end{array}$ & $\begin{array}{c}\text { Macaulay } \\
\text { Duration }\end{array}$ & $\begin{array}{c}\text { Modified } \\
\text { Duration }\end{array}$ & Convexity \\
\hline 1 & DTN237A & AA+ & 6.3816 & 6.3009 & 45.1906 \\
\hline 2 & CPFTH231A & $\mathrm{A}+$ & 6.3765 & 6.2959 & 45.1413 \\
\hline 3 & CPFTH237A & $\mathrm{A}+$ & 6.3748 & 6.2942 & 45.1250 \\
\hline 4 & BJC239A & $\mathrm{A}+$ & 6.3681 & 6.2876 & 45.0596 \\
\hline 5 & KTC23NA & $\mathrm{A}+$ & 6.3647 & 6.2843 & 45.0271 \\
\hline 6 & BJC23DA & $\mathrm{A}+$ & 6.3614 & 6.2810 & 44.9946 \\
\hline 7 & KTC23DA & $\mathrm{A}+$ & 6.3267 & 6.2467 & 44.6586 \\
\hline 8 & PL232A & $\mathrm{A}-$ & 6.3186 & 6.2387 & 44.5799 \\
\hline 9 & CK233A & $\mathrm{A}-$ & 6.3169 & 6.2371 & 44.5642 \\
\hline 10 & TICON235A & $\mathrm{A}$ & 6.2992 & 6.2196 & 44.3928 \\
\hline 11 & BEM236A & $\mathrm{A}$ & 6.2945 & 6.2149 & 44.3465 \\
\hline 12 & CENTEL239A & $\mathrm{A}$ & 6.2945 & 6.2149 & 44.3465 \\
\hline 13 & BTSC23NA & $\mathrm{A}$ & 6.2692 & 6.1900 & 44.1021 \\
\hline 14 & THAI23DA & $\mathrm{A}$ & 6.2522 & 6.1732 & 43.9368 \\
\hline & Average & & 6.3285 & 6.2485 & 44.6761 \\
\hline
\end{tabular}

The results in Table 3 show that the coupon bonds with duration and convexity of seven years have the same sensitivity to changes in interest rates. Results in Table 4 indicate that there is the same level of price sensitivity to interest rate changes for ten-year corporate bonds. This difference is minimal, and this implies that corporate bonds with same year to maturity are getting almost the same level of the price volatility resulting from changes in the same interest rates level. Therefore, the results show that bonds with seven years of maturity are less sensitive to interest rate changes compared with bonds with ten years maturity. Moreover, the duration of corporate bonds is less than its maturity. This finding is similar with the evidence commonly found in the literature (Ajlouni, 2012). According to credit quality, the study also finds that the price of bonds within the A-rated category move in the same degree. 
Table 4. Estimation of ten-year corporate bonds

\begin{tabular}{l|l|c|c|c|c}
\hline No. & $\begin{array}{c}\text { Corporate } \\
\text { Bonds }\end{array}$ & $\begin{array}{c}\text { Credit } \\
\text { Rating }\end{array}$ & $\begin{array}{c}\text { Macaulay } \\
\text { Duration }\end{array}$ & $\begin{array}{c}\text { Modified } \\
\text { Duration }\end{array}$ & Convexity \\
\hline 1 & GLOW265A & AA- & 8.7415 & 8.5912 & 84.6169 \\
\hline 2 & BDMS266A & AA- & 8.6819 & 8.5326 & 83.8222 \\
\hline 3 & DTN267A & AA+ & 8.6180 & 8.4698 & 82.9681 \\
\hline 4 & BEM266A & A & 8.5837 & 8.4361 & 82.5107 \\
\hline 5 & CENTEL269A & $\mathrm{A}$ & 8.5561 & 8.4089 & 82.1428 \\
\hline 6 & CPFTH267A & $\mathrm{A}+$ & 8.5350 & 8.3882 & 81.8605 \\
\hline 7 & KTC269A & $\mathrm{A}+$ & 8.5230 & 8.3764 & 81.7007 \\
\hline 8 & IVL26OA & $\mathrm{A}+$ & 8.4701 & 8.3244 & 80.9945 \\
\hline 9 & BJC269A & $\mathrm{A}+$ & 8.4357 & 8.2906 & 80.5353 \\
\hline 10 & KTC262A & $\mathrm{A}+$ & 8.4216 & 8.2768 & 80.3466 \\
\hline 11 & KTC262B & $\mathrm{A}+$ & 8.4216 & 8.2768 & 80.3466 \\
\hline 12 & BTSC26NA & $\mathrm{A}$ & 8.4160 & 8.2713 & 80.2716 \\
\hline 13 & CPFTH261A & $\mathrm{A}+$ & 8.4160 & 8.2713 & 80.2716 \\
\hline 14 & KTC26DA & $\mathrm{A}+$ & 8.3799 & 8.2358 & 79.7896 \\
\hline 15 & KTC26NA & $\mathrm{A}+$ & 8.3799 & 8.2358 & 79.7896 \\
\hline 16 & MPSC26DA & $\mathrm{A}+$ & 8.3205 & 8.1774 & 78.9966 \\
\hline 17 & BJC26DA & $\mathrm{A}+$ & 8.3073 & 8.1644 & 78.8202 \\
\hline 18 & THAl26DA & $\mathrm{A}$ & 8.2863 & 8.1438 & 78.5408 \\
\hline & Average & & 8.4719 & 8.3262 & 81.0194 \\
\hline
\end{tabular}

Compared with 2015, government bond yields at the end of 2016 trended upwards in reaction to rising U.S. yields based upon concerns over the U.S. economic policies under the new government administration. Overall, long-term government bond yields increased by 15 basis points. As a result, the study measures how small changes in the yield to maturity affect the price of the bond by 15 basis points, or $0.15 \%$. Table 5 below shows that the distribution of a bond's price will change when yield (interest rate) changes. Table 5 presents the contribution of each corporate bond of the duration in Eq. (5) and convexity in Eq. (8). The table is divided into two panels. Panel A displays the results of the coupon bonds with seven years of maturity, while Panel B contains the results for long term corporate bonds with ten years of maturity. 
Table 5. Estimation of Corporate Bonds Price Change

\begin{tabular}{l|l|l|l|l|l}
\hline $\begin{array}{l}\text { Panel A: Corporate Bonds with 7 years of } \\
\text { maturity }\end{array}$ & \multicolumn{3}{l}{$\begin{array}{l}\text { Panel B: Corporate Bonds with 10 years } \\
\text { of maturity }\end{array}$} \\
\hline $\begin{array}{l}\text { Corporate } \\
\text { Bonds }\end{array}$ & $\begin{array}{l}\text { Duration } \\
(\%) \\
\text { Change in } \\
\text { Yield }\end{array}$ & $\begin{array}{l}\text { Convexity } \\
(\%) \\
\text { Change in } \\
\text { Yield }\end{array}$ & $\begin{array}{l}\text { Corporate } \\
\text { Bonds }\end{array}$ & $\begin{array}{l}\text { Duration } \\
(\%) \\
\text { Change in } \\
\text { Yield }\end{array}$ & $\begin{array}{l}\text { Convexity } \\
(\%)\end{array}$ \\
$\begin{array}{l}\text { Change in } \\
\text { Yield }\end{array}$ \\
\hline DTN237A & 0.9451 & 0.9401 & GLOW265A & 1.2887 & 1.2792 \\
\hline CPFTH231A & 0.9444 & 0.9393 & BDMS266A & 1.2799 & 1.2705 \\
\hline CPFTH237A & 0.9441 & 0.9391 & DTN267A & 1.2705 & 1.2611 \\
\hline BJC239A & 0.9431 & 0.9381 & BEM266A & 1.2654 & 1.2561 \\
\hline KTC23NA & 0.9426 & 0.9376 & CENTEL269A & 1.2613 & 1.2521 \\
\hline BJC23DA & 0.9422 & 0.9371 & CPFTH267A & 1.2582 & 1.2490 \\
\hline KTC23DA & 0.9370 & 0.9320 & KTC269A & 1.2565 & 1.2473 \\
\hline PL232A & 0.9358 & 0.9308 & IVL26OA & 1.2487 & 1.2395 \\
\hline CK233A & 0.9356 & 0.9306 & BJC269A & 1.2436 & 1.2345 \\
\hline TICON235A & 0.9329 & 0.9279 & KTC262A & 1.2415 & 1.2325 \\
\hline BEM236A & 0.9322 & 0.9272 & KTC262B & 1.2415 & 1.2325 \\
\hline CENTEL239A & 0.9322 & 0.9272 & BTSC26NA & 1.2407 & 1.2317 \\
\hline BTSC23NA & 0.9285 & 0.9235 & CPFTH261A & 1.2407 & 1.2317 \\
\hline THAI23DA & 0.9260 & 0.9210 & KTC26DA & 1.2354 & 1.2264 \\
\hline Average & 0.9373 & 0.9322 & KTC26NA & 1.2354 & 1.2264 \\
\hline & & & MPSC26DA & 1.2266 & 1.2177 \\
\hline & & & BJC26DA & 1.2247 & 1.2158 \\
\hline & & & THAl26DA & 1.2216 & 1.2127 \\
\hline & & & Average & 1.2489 & 1.2398 \\
\hline
\end{tabular}

Panel A of Table 5 displays evidence that storongly suggests the predictability of percent price change in corporate bonds with seven years of maturity. On average, if interest rates rise $0.15 \%$ overnight, the price of the bond is expected to drop $0.93 \%$. Similarly, the convexity of a seven-year bond, on average, is 44.68 . If interest rates rise $0.15 \%$, the price average of a seven-year bond drops by $0.94 \%$. On other hand, when interest rates drop $0.15 \%$, the bond price is expected to rise from $0.93 \%$ to $0.94 \%$. The study finds that the bond with the highest volatility when interest rates change was DTN237A (Commucations sector), followed by CPFTH231A (Food and Beverage sector).

Panel $B$ shows the results for ten-year corporate bonds. The study finds that an average bond will move down (up) in price between $1.29 \%$ and $1.28 \%$ for every 15 -basis-point increase (decrease) in interest rates according to duration and convexity. The bond with the highest price volatility is GLOW265A (Energy sector). Thus, corporate bonds with 
ten years of maturity tend to be higher in price volatility than bonds with seven years of maturity when interest rates move up (down).

While duration and convexity can predict how much a bond's price will fluctuate for a given change in interest rate, this fluctuation actually depends on what the current interest rate actually is. In other words, duration and convexity are different for any given bond at different current interest rates. Thus, if interest rates change, duration and convexity changes, as well.

\section{Conclusion}

This study presents an empirical test of duration and convexity of the long-term corporate bonds in the Thai Bond Market in order to determine sensitivity of bonds prices to interest rate changes. The empirical results provide evidence that there is a small difference between the forecasting of corporate bond prices change when longterm government bond yields increased (decreased) by 15 basis points with duration and convexity. To sum up, duration and convexity can be used with great certainty for the forecasting of changes in bond prices for long-term corporate bonds.

\section{References}

Acharya, V. V., \& Carpenter, J. N. (2002). Corporate Bond Valuation and Hedging with Stochastic Interest Rates and Endogenous Bankruptcy. The Review of Financial Studies, 15(5), 1355-1383.

Ajlouni, M. d. M. (2012). Properties and Limitations of Duration as a Measure of Time Structure of Bond and Interest Rate Risk. International Journal of Economic Perspectives, 6(4), 46-56.

Bakshi, G., Madan, D., \& Zhang, Frank x. (2006). Investigating the Role of Systematic and Firm-Specific Factors in Default Risk: Lessons from Empirically Evaluating Credit Risk Models. The Journal of Business, 79(4), 1955-1987.

Bremmer, D., \& Kesselring, R. (1992). The Relationship between Interest Rates and Bond Prices: A Complete Proof. The American Economist, 36(1), 85-86.

Chance, D. M. (1990). Default Risk and the Duration of Zero Coupon Bonds. Journal of Finance, 45(1), 265-274.

Crabbe, L. E., \& Fabozzi, F. J. (2001). Corporate bond portfolio management. Hoboken, NJ: John Wiley \& Sons.

Duffee, G. R. (1998). The Relation Between Treasury Yields and Corporate Bond Yield Spreads. Journal of Finance, 53(6), 2225-2241.

Hubbard, R. G. (2008). Money, the Financial System, and the Economy (6th ed.). Boston: Pearson. 
Ivanovski, Z., Stojanovski, T., \& Ivanovska, N. (2013). Interest rate risk of bond prices on Macedonian stock exchange- Empirical test of the duration, modified duration and convexity and bonds valuation. Ekonomska Istrazivanja, 26(3), 47-62.

Jacoby, G. (2003). A Duration Model For Defaultable Bonds. Journal of Financial Research, 26(1), 129146.

Jarrow, R. A., \& Yildirim, Y. (2002). Valuing Default Swaps Under Market and Credit Risk Correlation. Journal of Fixed Income, 11(4), 7.

Keen, H. (2010). Bond Prices and Interest Rates: Techniques for Teaching Their Inverse Relationship. Journal of Global Business Management, 6(1), 1-10.

Kraft, H., \& Munk, C. (2007). Bond durations: Corporates vs. Treasuries. Journal of Banking \& Finance, 31(12), 3720-3741.

Livingston, M., \& Zhou, L. (2005). Exponential duration: A more accurate estimation of interest rate risk. Journal of Financial Research, 28(3), 343-361.

Longstaff, F. A., \& Schwartz, E. S. (1995). A Simple Approach to Valuing Risky Fixed and Floating Rate Debt. Journal of Finance, 50(3), 789-819.

Lwabona, G. (2000). Investment Basics XLI: Duration and convexity. Investment Analysts Journal, 29(51), 57-60.

Macaulay, F. R. (1938). Some theoretical problems suggested by the movements of interest rates, bond yields and stock prices in the United States since 1856. New York: National Bureau of Economic Research, Columbi University Press.

Samuelson, P. A. (1945). The Effect of Interest Rate Increases on the Banking System. The American Economic Review, 35(1), 16-27. 